\title{
STRATEGI MANAJEMEN KEPEMIMPINAN TERHADAP ETOS KERJA KARYAWAN DI BMT UGT SIDOGIRI TABANAN BALI
}

\author{
Ahmad Hamdi \\ ahmadhamdi289@gmail.com \\ Universitas Ibrahimy Situbondo
}

\begin{abstract}
ABSTRAK
Leadership is an ability that comes from a person, that is, a leader must have a leadership management strategy because a leader is identical to the kholifah on earth, he must have a strong attitude to face all the risks that exist in the company because a leader really protects his men. From the above statement in this thesis the researcher intends to find out more about the leadership management that is owned by the company and then to correlate it with the implementation of leadership management and supporting and inhibiting factors in the application of leadership management. As for this study, the authors chose BMT UGT Capem Tabanan Bali as the research object. And in taking data sources are the leaders and employees of this study.
\end{abstract}

Keywords: manajemen kepemipinan, etos kerja karyawan

\section{PENDAHULUAN}

Agama Islam yang sumber utamanya Al-Qu'an dan Al-Hadist sebagai tuntutan pada pedoman bagi kaum muslimin dan mempunyai fungsi tidak hanya mengatur dalam segi ibadah saja melainkan seluruh aspek manusia, termasuk mengatur dan memberikan tuntutan dalam masalah yang berkaitan dengan kepemimpinan tehadap etos kerja.

seorang pemimpin harus mempunyai startegi manajemen kepemimpinan yang berpotensi dalam meningkatkan etos kerja karyawan. Seorang pemimpin harus mengarahkan karyawannya dalam kepentingan guna maningkatkan kualitas perusahaanya agar bisa bersaing dengan perusahaan-perusahaan lain, karena perusahan maju dan tidaknya tergantung kepeda kepemimpinannya seorang pemimpin harus mempunyai sikap mental yang selalu mempunyai pandangan bahwa kehidupan hari ini lebih baik dari pada hari kemarin dan hari esok lebih baik dari pada hari ini, sikap yang demikian akan mendorong etos kerja karyawan untuk tidak merasa puas akan tetapi harus mengembangkan diri dan meningkatkan 
kemampuan etos kerja karyawan dengan cara selalu mencari ide-ide baru dalam meningkatkan peruasahaan.

manajemen adalah ilmu atau seni pengatur proses pemanfaatan sumber daya manusia secara efektif, yang di dukung oleh sumber-sumber yang lainnya dalam suatu organisasi untuk mencapai tujuan terterntu (Beni Ahmad Saebani, 2012).

Kepemimpinan adalah seseorang yang mempergunakan dan wewenang yang di arahkan kepada bawahannya untuk mengerjakan pekerjaan dalam mencapai tujuan. Menurut kartono mengemukakan kepemimpinan adalah seorang pribadi yang memiliki superioritas tertentu. Sehingga ia memiliki kewajiban dan kekuasaan untuk menggerakkan orang lain melakukan usaha bersama guna mencapai suatu tujuan tertentu. Proses kepemimpinan melibatkan keinginan dan niat, kerterlibatan yang aktif antara pemimpin dan bawahan untuk mencapai tujuan yang di inginkan bersama.

Di dalam islam, kepemimpinan identik dengan istilah kholifah yang berarti wakil, merupakan pemimpinan yang memikil amanah dan tanggug jawab unuk melaksanakan pemerintah dan menegakkan kebenaran. Seperti di jelaskan Allah di dalam firmnanya:

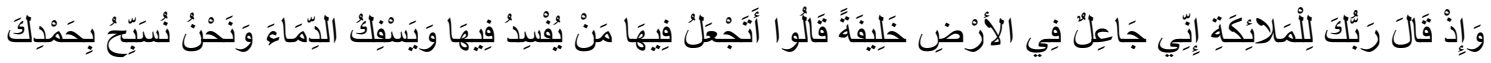

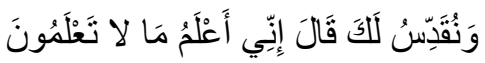

Artinya: Ingatlah ketika Tuhanmu berfirman kepada para malaikat: "Sesungguhnya Aku hendak menjadikan seorang khalifah di muka bumi". Mereka berkata: "Mengapa Engkau hendak menjadikan (khalifah) di bumi itu orang yang akan membuat kerusakan padanya dan menumpahkan darah, padahal kami senantiasa bertasbih dengan memuji Engkau dan menyucikan Engkau?" Tuhan berfirman: "Sesungguhnya Aku mengetahui apa yang tidak kamu ketahui".

Dalam ayat ini Allah SWT. Menjelaskan tentang kelebihan manusia di bandingkan dangan mahluk lainnya, manusia memiliki kemampuan untuk mengelolah alam, sehingga dia percaya dan di tunjuk untuk menjadi kholifah. 
Kepemimpinan dan manajemen merupakan dua konsep yang saling berhubungan,pemimpin dapat timbul dari kelompok-kelompok yang sama sekali terorganisasi, sedangkan manajemen hanya apabila struktur organisasi menciptakan peranan secara umum. Sedangkan kepemimpiann mengarah bagaimana seorang dapat mempengaruhi orang lain untuk dapat kordinasi dalam mencapai tujuan oraganisasi (Dadang Supriatna, 2014).

Etos kerja adalah pancaran dari sikap hidup manusia yang mendasar terhadap kerja. etos kerja adalah sifat, watak, dan kualitas kehidupan batin manusia, moral atau gaya estetik serta suasana batin mereka yang di refleksikan dalam kehidupan nyata (Ahmad Jannah Asifuddin, 2004).

BMT (baitul maal wal tamwil) merupakan lembaga keunagan mikro syari'ah (LKS) yang melayani lapisan bawah. BMT sangat di perlukan oleh masyarakat guna membantu meningkatkan taraf kehidupan kesejahteraan oleh karena itu BMT harus di jaga kelestarian dan tumbuh kembangkan sehingga mampu memberi kepemimpinan dalam jangkauan yang lebih luas dan lebih bermutu.

Lembaga BMT UGT capem sidogiri tidak hanya berkembang di kota atau di kabupaten yang memiliki basis alumni pondok pesantren sidogiri dan mayoritas penduduknya non muslim, Secara keseluruhan BMT Sidogiri berperan hanya untuk melakukan transaksi dalam berdasarkan sistem yang sesuai dengan syariat. BMT selalu memiliki pertumbuhan yang maju, sehimgga BMT sidogiri memiliki cabang dimana-mana salah satu cabang yaitu BMT UGT capem tabanan bali, awal masuk ke daerah bali, karna di daerah bali jarang sekali keuangan tidak ada lembaga BMT maka dari situ BMT sidogiri berinisiatif untuk membuka cabang di bali kususnya di kabupaten tabanan.

Sehingga banyak warga negara bali para pendatang yang membuka usaha untuk meneruskan keberlangsungan ekonomi usaha masyarakat yang menengah ke bawa mereka, oleh karena itu banyak masyarakat yang berposisi sebagai pendagang atau membutuk wadah untuk mendepositokan dan pembiyaan usaha masyarakat yang menengah ke bawah. .

Peneliti lebih fokus kepada manajemen kepemimpinan dan etos kerja karyawan. Manajemen sumber daya manusianya yang di lakukan oleh lembaga BMT UGT capem sidogiri tabanan bali yang di mulai dari rekrtutmen karyawan, 
melalui peramalan kerja, penarikan tenaga kerja, seleksi, penempatan kerja dan pelatihan serta pengembangan kerja, lembaga BMT UGT capem sidogiri tabanan harus mendukung terhadap etos kerja karyawan karena produktifitas yang tinggi dapat selalu meningkatkan kualitas yang tinggi dan harus di dukung oleh karyawan yang berkeinginan untuk perprestasi kerja guna mencapai hasil yang terbaik dalam pelaksanaan etos kerjanya.

Agar lebih produktif terhadap etos kerja karyawan dengan adanya pelatihan untuk melatih para karyawan juga memotivasi karyawan agar lebih efektif dalam menjalankan etos kerjanya agar mengerjakan sesuatu dengan benar dan tepat, serat dapat memperkecil atau meningkatkan kesalahan-kesalahan yang perlu di lakukan. oleh karna itu bagi karyawan yang etos kerja karyawannya giat, pekerja keras, ulet, produktif, tanggung jawab, maka akan di naikkan jabatannya, bukan Cuma hal itu karyawan BMT UGT capem tabanan bagi manajemen sumber daya manusianya bagus terapil tepat waktu yang sudah di tentukan oleh lembaga BMT UGT sidogiri tabanan maka karyawan yang demikian akan mendapatkan kompensasi dari pimpinanya itu sendiri.

\section{KAJIAN TEORI}

\section{Startegi}

strategi ialah cara atau alat yang di gunakan untuk mencapai tujuan akhir (sasaran atau objektif) untuk mencapai tujuan (Abdul Rival Darsono Prawironegoro, 2015). keberhasilan ialah perpaduan yang baik antara startegi dengan pelaksaan. Startegi adalah sebuah tindakan pengeloan bermacam-macam sumber daya organisasidan manjemen yang mengarah dan mengendalikan pemanfaatan sumber-sumber daya perusahaan (keuangan, manusia, peralatan dan lain-lain) melalui startegi yang di pilih, implemtasi startegi di perlukan untuk memperinci secara lebih tepat dan jelas bagaimana sesungguhnya pilihan startegi yang telah di ambil di realisasikan startegi keamanpun serta keterampilan manajer (Amirullah dan Haris Budiyono, 2004).

Startegi adalah penetapan tujuan dasar jangka panjang dan sasaran perusahaan dan penerapan serangkaian tindakan serta alokasi sumber daya yang penting untuk melaksanakan sasaran ini, startegi adalah kumpulan pilihan dasar atau kritis mengenai tujuan dan cara bisnis,ada juga strtegi merupakan rencana jangka 
panjang perusahaan untuk menyeimbangkan kekuatan dan kelemahan internal dengan kesempatan dan ancaman eksternal dalam mempertahan keuntungan kompetitif (Sedarmayani, 2013).

Startegi pengertian umum strategi, yaitu suatu proses yang menentukan adanya perencanaan terhadap para top manajer yang sungguh berarah pada jangka panjang perusahaan yang di sertai dengan penyusunan akan upaya bagaimna agar mencapai tujuan yang di harapakan.

Pengertian khusus strategi yaitu merupakan suatu tindakan yang bersifat terus menerus mengalami peningkatan dan di lakukan sesuai dengan sudut pandang tentang apa yang di inginkan serta di harapakan oleh para konsumen untuk waktu di masa depan. Dengan startegi ini, maka ada yang hampir di mulai dari apa yang selalu untuk bisa terjadi dengan terjadinya ada suatu kecepatan berinovasi pada lembaga yang baru dan juga perubahan-perubahan pola konsumen yang sangat memerlukan kemampuan inti atau juga kompetensi inti juga dalam bisnis di lakukan (Subekki Ridhotullah dan Muhammad Jauhar, 2016).

\section{Manajemen}

Manajemen adalah proses dimana pelaksanaannya dari tujuan tertentu yang di senggarakan dan di awasi, ada juga pengertian lain manajemen adalah fungsi dari dewan manajer biasaanya dinamakan manajemen untuk menetapkan lembaga kebijaksanaan mengenai apa macam produk yang akan di buat (Babun Suharto Fathurrozi, 2013). manajemen menjadi sangat penting artinya dari segala aspek kehidupan sehari karena manjemen menjadi icon yang urgen baik secara individual maupun secara kelompok. Pengertian manajemen yang paling sederhana "adalah seni memperoleh hasil memulai berbagi yang di lakukan oleh orang lain."

\section{Kepemimpinan}

Dalam suatu organisasi, faktor kepemimpiann memegang peran yang penting karena kepemimpiann itulah yang akan menggerakakn dan mengarahkan organisasi dalam mencapai tujuan dan sekaligus merupakan tugas yang tidak mudah. Kepemimpinan merupakn peranan manejer sebagai pimpinan adalah kunci sebagai penerapan perubahan startegi, peranan pimpinan adalah menyusun arah perusahaan mengkomonikasikan ini dengan karyawan, memotivasi para karyawan. 
Terry, menanggapi kepemimpinan sebagai kegiatan untuk mempengaruhi orang agar bekerja rela untuk mencapai tujuan bersama. Secara luas kepemimpinan di artikan sebagai usaha yang terorganisasi untuk mengelolah dan memanfaatkan sumbedaya manusiannya, materi, dan finanansial guna mencapai tujuan yang telah di tetapkan.

boss dan stogdill mengatakan bahwa kepemimipiann mempengaruhi aktivitas suatu kelompok dalam usaha untuk mencapai tujuan yang di tetapkan. anorga mengemukakan bahwa kepemimpinan adalah kemampuan untuk mempengaruhi pihak lain, melalui komonikasi baik langsung atau tidak lansung dengan maksud menggerakkan orang-orang agar penuh pengertian dan kesadaran, dan senag hati bersedia mengikuti kehendak pemimpin.

Jika definisi di simak dengan cermat akan melihat paling sedikit tiga hal, dari seseorang yang menduduki jabatan pemimpin di tuntut kemampuan tertentu yang tidak memiliki oleh SDM organisasi, keikut sertaan sebagai elemen penting dalam menjalankan kepemimpinan.. kemampuan mengubah "egosentrisme" para bawahan menjadi "organisasi-sentrisme ${ }^{1}$

\section{METODE PENELITIAN}

Urgensitas metode dalam penelitian ini adalah untuk mempermudah memperoleh data yang valid dan dapat membantu ketajaman analisis data. Adapun jenis Penelitian ini menggunakan metode kualitatif, karena permasalahan yang akan diteliti belum jelas, holistic, kompleks, dinamis dan penuh makna.

\section{Sumber Data}

Menurut teori penelitian ini kualitatif, agar penelitiannya betul-betul berkualitas, data yang dikumpulkan harus lengkap. Selain bersifat penelitian lapangan, sumber data yang digunakan peneliti dalam hal ini bisa melalui data primer dan sekunder. (Sugiono, 2012)

\section{TeknikPengumpulan Data}

Secara umum dalam penelitian kualiatif ada empat macam teknik pengumpulan data, yaitu observasi, wawancara, dan dokumentasi.

a. Metode observasi

\footnotetext{
${ }^{1}$ Ibid, 213-214
} 
Metode Observasi adalah metode yang digunakan dengan cara melakukan pengamatan langsung dan pencatatan secara sistematis terhadap fenomena-fenomena yang diselidiki. Melalui metode observasi ini peneliti akan mengumpulkan data berkaitan dengan persoalan yang diteliti dan sumber data peneliti jumpai.

b. Metode Interview.

Interview atau wawancara diartikan dengan suatu percakapan tanya jawab lisan antara dua orang atau lebih yang duduk berhadapan secara fisik dan didasarkan pada suatu masalah tertentu.

c. Metode Dokumentasi.

Dokumentasi merupakan laporan tertulis dari berbagai kondisi di suatu istansi yang isinya terdiri dari penjelasan serta pemikiran tentang suatu peristiwa dan proses penjabaran dan penyelesaian peristiwa tersebut. Melalui metode ini peneliti akan menggali data terkait gambaran umum tentang Penerapan Dynimic Governance BUMP pondok pesantren Slafiyah Syafi'iyah.

3. Teknik Analisis Data

Dalam penelitian kualitatif analisis data dilakukan pada saat proses pengumpulan data yang sedang berlangsung, dan dilakukan setelah data terkumpul dalam beberapa priode. Peneliti akan melakukan analisis terhadap jawaban informan. Menurut Miles dan Huberman, ada tiga aktivitas dalam analisis data, yaitu data reduction, data display, dan conclusion drawing/verificatio.

4. Pengecekan Keabsahan Data

Keabsahan data merupakan cara yang sangat urgen untuk pengecekan kesahihan (validitas) dan keterandalan (reliabilitas) data. Peneliti merupakan kerja ilmiah, untuk melakukan ini mutlak di tuntut secara objektivitas, untuk memenuhi kriteria ini dalampenelitian maka kesahihan (validitas) dan keterandalan (reliabilitas) harus dipenuhi, kalau tidak maka proses penelitian itu perlu di pertanyakan keilmiahannya. (Iskandar, 2008)

Dalam sebuah penelitian kualitatif keilmiahan merupakan faktor utama, menjaga keilmiahan tersebut dapat dilihat data yang ada, karena kesalahan mungkin saja terjadi dalam pencarian data, sedangkan data biasa terjadi dari dalam penelitian sendiri dan mungkin juga terjadi dari informan. (Lexy J Moleong, 2014) 


\section{HASIL DAN PEMBAHASAN}

\section{Penerapan Manajemen Kepemimpinan Dalam Meningkatkan Etos Kerja Karyawan Di BMT UGT Tabanan Bali}

Fakta yang di temukan dilapangan sudah sesuai dengan apa yang dalam teori bahwasanya seorang pemimpin haruslah memberi setiap hari motivasi agar para karyawan giat untuk bekerja sama, sehingga seorang pemimpin haruslah mempunyai rasa tanggungan terhadap jabatannya, memang hal demikian seorang pemimpin seringsering memotivasi terhadap ada bawahannya itu baru serang pemimpn yang pantas untuk di jadika pemimpin bedarakan fakta dan teori itu sudah sesuai

Menurut teori bahwa seorang pemimpin harus mempunyai jiwa-jiwa keberanian dari segi manapun, sedangkan faktanya memang demikian mempunyai rasa ingin tahu terhadap sesuatu yang tidak di ketahuai. opiniya memang hal demikian bahwa seoarang pemimpin harus kuat mental terhadap sesuatu yang di hadapi namanya juga seorang pemimpin karna ada kesalahan apa di lembaganya nanti yang di tanyain pasti siapa yang memimpin.

Berdasarkan teori sosial yang tidak hanya mengacu orang kaya yang menjadi pemimpin namun orang biasa juga bisa jadi seorang pemimpin, sedangkan fakta yang ada sama dengan ada yang ada dalam teori sasial bahwa di sana tidak hanya mengacu kepada orang yang keluarga kolongmerat melainkan karna potensi yang di anggap mampu, jadi sepantasnya memang begitu tidak serta merta karna kekayaannya, namun karna mempunyai jiwa-jiwa dan potensi yang mampu untuk menghendel lembaga BMT UGT ini .

Berdasarkan teori yang ada bahwa etos merupaka karakter atau watak sebagai mestinya seorang pemimpin harus mampu melewati yang karyawannya yang memiliki watak keras sedangkan fakta yang ada pemimpinnya mampu ketika para karyawan memiliki watak yang keras jadi sesuai apa yang ada di teori. Memang hal demikian bahwasanya seorang pemimpin haruslah mampu ketika karyawannya yang mempunyai watak yang keras, karna pemimpin yang baik harus bisa

Sebagain besar definisi kepemimpinan mencerminkan asumsi bahwa kepemimpinanya berkaitan dengan proses yang di sengaja dari seseorang untuk 
menekankan pengaruhnya yang kuat terhadap orang lain untuk membimbing. Bedasarkan teori bahwasanya seorang pemimpin haruslah menitik beratkan kepada pengarahan yang harus pekah terhadap bawahannya sedangkan faktanya seorang pemimpin bener-bener mengarahkan kepada apa yang ingin di capai bersama maka sesuai antara fakta dan teori, sehingga seorang pemimpin bener-bener memberi pengertian terhadap karyawannya. Memang hal demikian bahwasanya seorang pemimpin sering-seringlah memberi arahan dan bimbingan terhadap anak buahnya, karna ketika anak buahnya ber etos kerjanya baika itu terlaetak kepada kepemimpinannya.

\section{Faktor Pendukung Penghambat Dalam Penerpan Manajemen Kepemimpinan di BMT UGT Tabanan Bali}

Faktor pendukung Menajemen Kepemimpinan

Pemimpin merupakan faktor yang terpenting dalam kehidupan, terutama dalam aktivitas`suatu lembaga kegiatan ekonomi maju mundurnya suatu perusahaan biasanya di tentukan dari kepemimpinan juga tingkat etos kerjanya. Melihat fakta yang ada tidak melakukan sedemikian apa yang dalam teori tidak sesuai. Seharusnya tidak hal demikian seorang pemimpin haruslah menentukan kapan memberi pekerjaan tidak langsung memberikan begitu saja kasik arahan dulu agar tidak bingung terhadap bawahannya karna pemimpin yang bijak adalah menentukan para bawahanya kepada apa yang harus di tuju.

pemimpin yang di kenali sebagai pendukung utama dan sponsor dari perubahan itu harus terus menerus memberikan perhatian dan pengesahan yang memberikan tanda bahwa komitmen untuk melaksanakan hingga selesai. antusiasme dan dukungan awal bagi sebuah perubahan besar dapat menurun saat di hadapakan dengan masalah, terjadinya kemunduran dan orang baru memahami biaya yang di perlukan orang yang di lihat dari pemimpin mereka untuk mencari tanda- tanda kometmen yang berkelanjutan terhadap sasaran dan visi perubahan, para pendukung akan hilang dan lawan terdorong untuk meningkatkan perlawanan yang lebih jelas, perhatian dan pengesahan yang berkelanjutan memberikan tanda kometmen pemimpin untuk melihat program perubahan terus berjalan hingga mencapai akhir yang berhasil. bukan membutuhkan dukungan bukan hanya dari dalam organisasi melainkan butuh dari luar menjadi seorang pemimpin bukan dari paksaan melaikan harus tertanam dari diri sendiri, namun 
fakta yang ada bahwa pemimpinya bener-bener memberi perubahan yang bisa membut perusahaan berkembang untuk meningkatkan tingakat keberhasilan perusahaan bmt ugt sidogiri hingga mencapai tingkat keberhasilan. Hal ini memanglah demikian seorang pemimpin bagaimana harus menemukan titik akhir untuk meningkatkan perusahaan akan terus maju sehingga bisa mencapai target yang ingi di capai.

Bedasarkan teori bahwasanya seoarang pemimpin haruslah bener-bener mangarahkan semaksimal mungkin, sedangkan fakta tidak memberi arahan semaksimal mungkin karna pemimpinnya tidak tau mengarahkan. Seharusnya tidak sedemikian tapi pemipinnya di BMT berusaha untuk memberi arahan semaksimal mungkin agar tau bagaimana mencari pemimpin yang hebat maka harus belajar ke yang lebuh tau agar mampu untuk mendidik bawahannya karna seorang pemimpin harus lebih pinter dari pada anak buahnya.

Berdasarkan teori yang ada Bagi para manajer haruslah memikirkan bagaimana aktivitas dan pengembangan tertentu mensosialisasikan kepada karyawan mereka, fakta yang ada seorang pemimpin memberi peluang kepada karyawannya untuk mensosialisakan tentang pekerjaannya, jadi jika di kaitan antara fakta dan teori sesuai. Memanglah demikian harus banyak menanyakan bagaimana aktivitas ke depannya seorang pemimpin agar tidak bingung kedepannya.

Berdasarkan teori yang ada bahwa pemimpin harus punyak kemampuan yang tidak di miliki oleh sumber daya manusianya kemampuan mengubah sumber daya manusia menjadi organisasi yang handal, jika di kaitakn dengan fakta yang ada maka sesuai yang apa yang sudah ada dalam teori. Memang hal demikian karna setiap pemimpin harus punyak kemampuan yang lebih terhadap karyawannya.

Menurut teori bahwa seorang pemimpin bahwasanya seorang pemimpin haruslah mampu mengambil tindakan yang korektif, sedangkan fakta yang ada seorang pemimpin melihat situasi para karyawannya jika karyawannya mau tentang apa yang di putuskan seorang pemimpinnya maka dari pemimpin akan di tindak lanjuti. Memanglah demikian seorang p-emimpin harus mampu dalam pengambilan keputusan alangkah jangan di putuskan dulu jika belum ada kesepakan dari bawahan, karna bawahan juga berhak antara keputuasan itu berlanjut atau tidak agar tetapa kompak.

Faktor Pengambat Manajemen Kepemimpinan 
lingkungan seperti ketidak pastian inovasi teknologi, dan perubahan demografi mempengaruhi startegi kerjanya, kondosi ekonomi: menuntut perusahaan meningkatkan produktivitas ke arah yang lebih baik agar berdaya saing di tenggi lingkungan bisnis yang kompotitif mengubah karakteristik kerjanya, hal ini berkaitan masalah demografis misalnya jumlah angkatan kerjanya usia mudah, tenaga kerjanya wanita dalam angkatan kerja semakin meningkatkan.

Menurut teori yang ada bahwasanya cara controlingnya haruslah tepat waktu tidak memolorkan waktu agar mencapai prestasi yang ingin di capai, Oleh karna itu fakta dan teori tidak selaras karna di BMT UGT tabanan bali tidak menentu kadang tertib kadang tidak. Jadi fakta antara teori itu tidak sesuai. Seharusnya tidak demikian bagaimana lembaga BMT UGT harus memenuhi tertib tidak memolorkan waktu agar lebih efektif dan efesien cara controlingnya.

Dari teori yang tercantum menjelaskan bahwa seorang pemimpin haruslah bertindak demi memajukan lembanganya, sedangkan fakta yang ada seorang pemimpin tidak punya rasa gereget terhadap karyawannya yang masih kurang paham terhadap kemampuan karyanwannya, oleh karna itu seorang pemimpin haruslah pekah terhadap anak buahnya, maka fakta dan teori jika di gabungan tidak sesuai dengan teori. Seharusnya seorang pemimpin haruslah punyak rasa gereget terhadap karyawan yang masih kurang potensinya karna sebagai kaaryawan harus perduli dalam segala hal apapun namanya juga pemimpin harus. ${ }^{2}$

\section{KESIMPULAN}

Kepemimpinan adalah sebuah proses untuk mempengaruhi para bawahannya guna mencapai sesuatu yang di tuju. dimana seorang pemimpin harus memberi motivasi terhadap bekerja sama dengan karywannya agar kompak sesuai dengan apa yang di, Penerapan kepemimpinannya etos kerjanya karyawan di BMT UGT Tabanan Bali. sesuai dengan ciri-ciri kepemimpinannya juga etos kerjanya yaitu: 1) bertanggung jawab dalam menjalankan tugas, selalu memberi arahan terhadap karyawannya. Yang terpenting dukungan seorang karyawan sering-sering memberi komitmen dan inovasi terhadap lembaganya memberikan tanda komitmen pemimpin untuk melihat program perubahan terus berjalan hingga mencapai akhir yang berhasil, sedangkan

\footnotetext{
${ }^{2}$ Lihat Bab II hal 15
} 
penghambatnya seorang pemimpin lingkungan yang kurangnya inovasi, yang mempengaruhi startegi manajemen kepemimpinannya juga memolorkan waktu terhadap pekerjaannya

\section{Daftar Pustaka}

Abdul Rival Darsono Prawironegoro. (2015). Manajemen Strategi. Jakarta: Metra Wecana.

Abdullah Hamid. (2017). Pendidikan Karakter Berbasis Pesantren. Surabaya: Imtiyaz.

Abu Huraerah. (2008). Pengorganisasian dan Pengembangan Masyarakat. Bandung: Humaniora.

Ahmad Jannah Asifuddin. (2004). Etos Kerja dalam Ajaran Islam. surakarta: Muhammadiya. Amirullah dan Haris Budiyono. (2004). Pengantar Manajemen. Yogyakarta: Gerehana IImu. Babun Suharto Fathurrozi. (2013). Ekonomi Koperasi. Jember: Stain Jember Press.

Beni Ahmad Saebani. (2012). Filsafat Manajemen. Bandung: CV. Pustaka Setia.

Boon Siong Neo, Geraldine Shen. (2007). Dynamic Governance: Embedding Culture, Capabilitas and Change In Singapore. Singapore: Word Scientific Publishing.

Dadang Supriatna. (2014). Manajemen. Tanggerang Selatan: Universitas Terbuka.

Iskandar . (2008). Metode Penelitian Pendidikan Sosial. Jakarta: GP Press.

Lexy J Moleong. (2014). Metode Penelitian Kualitatif. Bandung: Alfabeta.

Muhammad Daud Gunawan. (2008). Pembangunan Berdimensi Keumatan. Bandung: Alfabeta.

Mujamil Qomar. (2001). Pesantren, Dari Transformasi Metodologi Menuju Demokrasi. Jakarta: Erlangga.

Mussa Asy'arie. (1997). Islam Etos Kerja dan Pemberdayaan Ekonomi Ummat. Yogyakarta: Alfabeta.

Sedarmayani. (2013). Manajemen Sumber Daya Manusia. Bandung: PT Refika Aditama.

Subekki Ridhotullah dan Muhammad Jauhar. (2016). Pengantar Manajemen. Jakarta: Prestasi Pustakarya.

Sugiono. (2018). Metode Penelitian Kuantitatif dan R\&D. Bandung: Alfabeta.

Sugiono. (2012). Metode Penelitian Pendidikan. Bandung: Alfabeta.

Veithzal Rivai. (2004). Manajemen Sumber Daya Manusia Untuk Perusahaan: Dari Teori ke Praktik. Jakarta: PT. Raja Grafindo Persada. 
Volume 2, No 1, Februari 2021

Jurnal al-Idārah | 150 